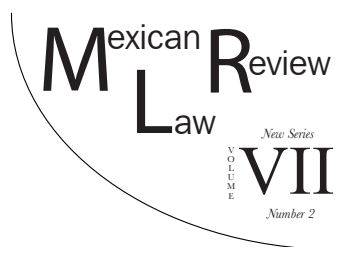

\title{
THE BEST INTERESTS OF THE MINOR AS A PRINCIPLE OF INTERPRETATION IN MEXICAN CIVIL LAW
}

\author{
Gisela María PéRez Fuentes* \\ Karla Cantoral Domínguez**
}

\begin{abstract}
From a doctrinal perspective and based on a case study, this article analyzes the way in which the best interests of the minor has become an important principle of interpretation in Mexico's legal life. This is observed in the evaluation of different situations in which the federal Fudicial Branch has resolved conflicts dealing with fundamental rights, taking into account family law-related issues. Moreover, there are important cases that neither the state nor local courts have resolved as they specifically deal with the protection of minors in the printed media. Therefore, as of the constitutionalization of Civil Law, the traditional form of this particular branch of law has been revised, considering the rescue of the person and in compliance with the international treaties that Mexico has signed, as a form of legal argument.
\end{abstract}

KeY Words: Best interests of the minor, family law, weighting, personality rights of minors, a child's right to identity.

Resumen. El presente artículo analiza de forma doctrinal y a partir de un estudio de casos la forma en que el interés superior del menor entra como un principio interpretativo importante a la vida jurídica mexicana a través de la va-

* Research Professor at the University Juarez Autónoma of Tabasco, Mexico. Leader of the "Studies of Civil Law" Academic Body, she is a Level II member of the CONACYT [National Researcher System]. She is currently the Coordinator of the Doctorate in Law Studies accredited by the PNPG CONACYT. Since 2005, she has conducted research on the person, moral injury, personality rights and especially the right to honor, privacy and image and the right to identity and personal data protection, among others. Since 2012 she has been responsible for the "Observatorio de la Información en el Sureste de México", which is currently conducting research on the protection of the personality rights of minors.

** Research Professor at the University Juarez Autónoma of Tabasco, Mexico. She is part of the "Studies of Civil Law" Academic Body and is a Candidate level member of the CONACYT [National Researcher System]. She is currently the coordinator of the Master's Program of Law Studies, accredited by the PNPC CONACYT. She conducts research on personal data, medical liability, rights of access to information and transparency. Since 2012, she has formed part of the "Observatorio de la Información en el Sureste de México". 
loración de distintas situaciones donde el Poder Fudicial de la Federación ha dado solución a conflictos de derechos fundamentales, considerando temas propios de derecho de familia. Además, existen casos relevantes que ni los Tribunales Locales ni Estatales han resuelto como es precisamente la protección del menor en los medios de comunicación impresa. Es asi que a partir de la "constitucionalización" del Derecho Civil se ha reconsiderado el Derecho Civil tradicional, en función del rescate de la persona y en cumplimiento de los tratados internacionales que ha suscrito México, como un camino de argumentación jurídica.

Palabras Clave: Interés superior del menor, derecho de familia, ponderación, derechos de la personalidad de los menores, derecho a la identidad del menor.

TABLE OF CONTENTS

I. INTRODUCTION

II. The Principles of Interpretation in Mexican Givil Law:

From Interpretation to Argumentation

III. The Best Interests of the Minor: A Legal and Argumentative Framework through International Treaties and

Comparative Law

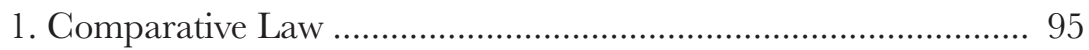

2. Domestic Legal Framework ....................................................... 98

3. Law for the Protection of the Rights of Children and Adolescents.

4. The Best Interests of the Child: Weighting as an Argumentation Framework

IV. Case studies from Mexican Jurisprudence

1. Balancing between the Rights of Privacy of Minors and the Right to Expert Evidence Presented by the Opposing Party

2. Principle of Equality between Men and Women and the Minor's Right to Receive Sustenance

3. Content and Scope of the Minor's Right to the Identity Based on the Best Interests of the Minor.

4. The Minor's Right to an Identity and the Very Personal Act of Acknowledging of Parentage

5. The Minor's Right to an Identity and the Rights Derived from the Concept of Family

6. The Right of Paternity and the Right to an Identity.

7. A Child's Right to Express His Opinion in the Jurisdictional Procedures that Affect His Legal Sphere. 
8. Cases of Cohabitation of the Parents with the Child for Reasons of Divorce, Guardianship and Custody, Parental Rights and Adoption ....

9. The Principle of Guardianship, Custody and Parental Authority of the Parents Consisting in the Fact that Minors Should Not Be Separated from Their Parents against the Will of the Parents in Weighting the Best Interests of the Child

10. Legal Adoption by a Same-Sex Partnership and the Principle of the Best Interests of the Child

11. The Best Interests of the Child and the Tender Years

Doctrine

V. Conclusion.

\section{INTRODUCTION}

The constitutional scope of the best interests of the minor as part of Mexico's constitutional provisions was incorporated at the beginning of the $21^{\text {st }}$ century. This has been yet another sign of rekindling Mexican law after the completely positivist tendency the law adhered to during most of the $20^{\text {th }}$ century. The significance of this study goes beyond a philosophical analysis since the rescue of the pro homine principle in the structure of rights has become much more apparent in the structure of the Mexican legal system.

The above seems to disrupt traditional civil law, which according to Mexican theory was asset-based and dogmatic to an extreme. Thus, the freedom of choice was limited by social interests while the family hierarchy would fall apart in the face of the interest of the weakest, and especially in the case of children, the so-called minors.

This work starts from the hypothesis that the principle of the best interests of the child, as part of family law, has the distinction of being a fundamental essential right, which is also called a "hard law" in the theory of fundamental rights. The reason for this is that this principle is found within the generic wording of the values established in the current Mexican legal system, the function of which is not only that of filling in loopholes, but also that of assisting in the interpretation and weighting of fundamental rights.

In this article, a brief study is made of the weighting performed in international treaties regarding any possible conflict with other rights. In the case of freedom of expression, related conflicts are apparently solved by some Mexican laws. However, flagrant violations appear in the media, especially in southern Mexico, in terms of identifying child victims through images, names and addresses. Minor detainees who have yet to stand trial are also identified in the same way, thus contributing to a violation of the presumption of innocence. From our point of view, this is a very socially sensitive issue as it is a 
form of generating even more psychological and social violence in a country already steeped in violence. The importance of the freedom of expression must be tied in with social responsibility, without implying a limitation on this right because caring for a country's children is the main social responsibility of professionals and of society in general.

The general objective of this work is to explain how the best interests of the minor has inserted itself as an important principle of interpretation in Mexico's legal life by examining various situations in which the Federal Judicial Branch has ruled on conflicts between fundamental rights. However, there are extremely difficult cases that neither the State nor local courts have been able to resolve as said cases deal specifically with the protection of minors in the media. This issue forms part of an applied research project on the protection of minors' right to personality in the printed media carried out in the State of Tabasco.

Therefore, this work aims to show that Mexican law has revised its traditional civil law based on the rescue of the person and in compliance with the international treaties Mexico has entered into, breaking with the radical positivism in judicial and legislative spheres which has undoubtedly affected Mexican society in solving conflicts of a social and political nature.

\section{The Principles of Interpretation \\ in Mexican Givil Law: \\ From Interpretation to Argumentation}

The concept of general principles ${ }^{1}$ of law has varied in different national legal systems depending on the philosophical current on which each political, social and legal organization bases its theory of the law. In terms of doctrine, two ideologies have defined the content of the general principles of law: the positivist one and natural law. ${ }^{2}$ The first sees the legal system as a complement and support for the principles sought by legislation itself that will in turn make up for certain loopholes in the law. The natural law current is based

1 While upholding a positivist position, Mexican doctrine covered a very wide range of thoughts on the matter. See Ignacio Galindo Garfias; Interpretación e Integración de la ley, XIV 56 Revista de la Facultad de Derecho de México, 1013-1033 (1964); Eduardo García Máynez; Los Principios Generales del Derecho y la Distinción entre Principios furídicos Normativos y no normativo, in Ensayos FiLosóficos-JuRídicos 282 (Universidad Veracruzana, 1959).

2 Recasens Siches, a defender of natural law in Mexico, pondered the matter, stating that "...in any case, the principle that, from among all human interests, there are those of a higher hierarchy that consist of providing the means to fulfill the values that can be met are found in the individual and their free choice must always be kept in sight." See Luis Recasens Siches; Introducción al estudio del Derecho 326 (Porrúa, 1981). 
on philosophical, ethical and humanist values in which the concept of justice and equity is highlighted through legal provisions. ${ }^{3}$

An exception to the positivist nature ${ }^{4}$ that characterized Mexican law in the $20^{\text {th }}$ century was established for civil matters in the civil sector in the last paragraph of Article 14 of the 1917 Constitution. ${ }^{5}$ It can be argued then that the Mexican courts have oscillated between both trends. The Judiciary has been charged with the duty of not only determining the nature of these principles, ${ }^{6}$ but also the scope of civil trials. The Mexican Constitution expressly mentions the latter, stating that matters of a civil nature are not seen as restricted in the way that might be concluded from a strict interpretation of the cited constitutional article, but even without the positivization of other items of business, it is often admitted to the degree in which they are deemed the more general wording of the values inherent in current understanding of the law. ${ }^{7}$

In Mexican doctrine, the general principles of law have been identified as:

- Dogmas, which link principles with the concept of immutability and without the need for further proof. ${ }^{8}$

- Maxims, which are proposals generally accepted by those engaged in the science of the law and that do not necessarily coincide with the

3 Other authors have pointed out that the principles of law, its purposes and legal values are strongly linked. Thus, these values tend to be confused and are understood as criteria for judging and acting; they are considered ways to facilitate the means to an end or even principles of law. Legal values are an important part of the law, and as such, principles may stem from said values. A three-dimensional perspective of the law also implies that in the case of shortcomings or flaws in the law, the overall objectives of a legal system can be met when principles are applied. See Juan Espinoza; Los Principios contenidos en el Título Preliminar del Código Givil Peruano de 1984, 423 (Pontificia Universidad Católica del Perú, Fondo Editorial, 2005).

4 This is in terms of the philosophical theory.

5 Article 14 of the 1917 Mexican Constitution states that “...En los juicios del orden civil, la sentencia definitiva deberá ser conforme a la letra o a la interpretación jurídica de la ley, y a falta de ésta se fundará en los principios generales del derecho.” [...In civil suits the final judgment shall be according to the letter or the juridical interpretation of the law; in the absence of the latter it shall be based on the general principles of law.] See Constitución Política de los Estados Unidos Mexicanos [Const.], as amended, Diario Oficial de la Federación [D.O.], 5 de Febrero de 1917 (Mex).

${ }^{6}$ In the Mexican legal system it has been traditionally thought that, in deciding on matters brought before them, judges are subject to the observance of not only positive legal law, but also the general dogmas that form and give coherence to all legal provisions, which are known as General Principles of Law. See Principios generales del Derecho. Su función en el ordenamiento Jurídico. Pleno de la Suprema Corte de Justicia [S.G.J.N.] [Supreme Court], Semanario Judicial de la Federación y su Gaceta, Octava Época, tomo III, Enero-Junio 1989, Tesis P./J. 228881, Página 573 (Mex).

${ }^{7}$ Id.

8 See Fausto Rico-Álvarez et al., Introducción al estudio del Derecho Givil y PerSONAS 154 (Porrúa, 2009) 
laws themselves. We concur with this position in that the principles are guidelines that emanate validity to all that is construed from said principles. ${ }^{9}$

The Introductory Provisions of the 1928 Civil Code for the Federal District ${ }^{10}$ sets forth some rules that have come to be regarded as general principles of law, although not the only ones, ${ }^{11}$ of the Civil Law itself. ${ }^{12}$ Some authors have argued that the more contemporary Mexican law assumes the position of natural law ${ }^{13}$ since Mexican legislation contains an extensive variety of

9 “...toda institución jurídica se rige por principios generales de derecho, que responden a ideales como la equidad y la justicia y a principios como son: la buena fe, la idea de responsabilidad y la apariencia legal del acto." [...all legal institutions are governed by general principles of law, which respond to ideals like equality and justice and to principles like: good faith, the idea of liability and semblance of legal right.]. Sea Sociedades cooperativas. Nulidad de

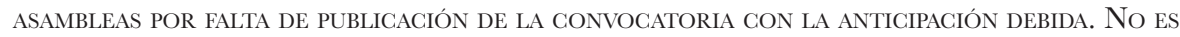
APLiCABle SUPLetoriamente LA LEy general DE sociedades merCantiles, Tribunal Colegiado de Circuito [T.G.C.] [Collegiate Circuit Court], Semanario Judicial de la Federación y su Gaceta, Décima Época, libro XV, Diciembre 2012, Tesis I.3o.C.1042 C, Página 1567 (Mex). All translations are by the authors unless otherwise indicated.

10 By Decree of the Congress of the Union published in Diario Oficial de la Federación (DOF), May 29, 2000 (Mex), on being adopted at a federal level the Civil Code of 1928 changed its name to Código Civil Federal [CGF] [Federal Civil Code], as amended, Diario Oficial de la Federación [D.O.], 26 de mayo de 1928 (Mex.). See Gisela M. Pérez Fuentes Et Al., El Derecho en México 36 (2012).

11 Article 2 of the Civil Code for the Federal District establishes legal equality. Article 16 refers to the fact that no person shall cause damage to another. Article 17 regulates the principle of unjust enrichment. See Código Givil para el Distrito Federal [G.C.D.F.] [Civil Code of the Federal District], as amended, Diario Oficial de la Federación [D.O.], 26 de mayo de 1928 (Mex.).

12 Artículo 18. El silencio, obscuridad o insuficiencia de la ley, no autorizan a los jueces o tribunales para dejar de resolver una controversia [Article 18. Silence, obscurity or insufficiency of the law do not authorize judges or courts to leave a conflict unresolved]. Artículo 19. Las controversias judiciales del orden civil deberán resolverse conforme a la letra de la ley o a su interpretación jurídica. A falta de ley se resolverán conforme a los principios generales de derecho. [Article 19. Legal disputes for civil matters shall be resolved to the letter of the law or its legal interpretation. In the absence of law, said disputes shall be settled according to the general principles of law.] Artículo 20. Cuando haya conflicto de derechos, a falta de ley expresa que sea aplicable, la controversia se decidirá a favor del que trate de evitarse perjuicios y no a favor del que pretenda obtener lucro. Si el conflicto fuere entre derechos iguales o de la misma especie, se decidirá observando la mayor igualdad posible entre los interesados [Article 20. When there is a conflict of laws, and in the absence of a specific applicable law, the dispute will be decided in favor of the one that attempts to prevent damages and not in favor of the one seeking profit. If the conflict were between rights that are equal or of the same kind, it will be decided by adhering to the greatest measure of equality possible among the interested parties]. See Código Civil Federal [C.C.F.] [Federal Civil Code], as amended, Diario Oficial de la Federación [D.O.], 26 de Mayo de 1928 (Mex).

13 Edgar Baqueiro Rojas \& Rosalía Buenrostro Báez, Derecho Givil. Introducción y Personas 36-37 (Oxford, 2000). 
abstract concepts with a wide-ranging scope of interpretation, such as the principles of solidarity, social utility, collective interests, justice and equality. However, it should be noted that the tendency to protect human rights and, as an extension, to protect the rights of personality and weaker social groups, at least in terms of legislation, reflects a neoconstitutionalism ${ }^{14}$ in which the principles of the civil law cease to be apolitical and begin to intertwine with and expand to form part of the constitutional system.

Mexico has understood that it needs to update its Civil Law and the provisions regulating it so as to enrich the social community, given the historical conditions that have shaped family law provisions ${ }^{15}$ in the country.

The defense of human rights in the Mexican Constitution and recent reforms in this direction, coupled with the differences in the composition and defense of family law in Mexico, have allowed for new interpretive guidelines that mark substantial changes, as embodied in other interpretative principles in the constitution and some civil legislation. ${ }^{16}$ As primarily revealed in its social and political norms, the Mexican Constitution has ceased to be an exclusive source of public law to become a framework law. ${ }^{17}$ Thus, the propersona principle, the protection of the family and the protection of weaker social groups, in which children are placed at the top of the list, have become priority issues in the constitution, at least in terms of legislation.

It cannot be denied that the Civil Code has formally lost its exclusively supplementary nature to attain constitutional status. Thus, the traditional principles of law have come to form part of constitutional law. ${ }^{18}$ In response to the critics of civil law who support the de-codification and, therefore, the disintegration of civil order ${ }^{19}$ we defend the resurgence of the common

14 For the defenders of this position, the Constitution is not limited to establishing areas of responsibilities or dividing public powers. It contains high levels of material, secondary or procedural rules or substantive laws that are grounded on the exercise of the State and of the constitutional judiciary branches that apply the principles of weighting, proportionality, reasonableness and maximization of fundamental rights. See Miguel Garbonell, Teoría del NEOCONSTITUCIONALISMO. ENSAYOS EScogidos 10 (IIJ-UNAM, 2007).

15 About the composition of Mexican law, see El Derecho en MéXico, supra note 10, at 34.

16 Mexican Supreme Court opinions have gone beyond the use of formal logic in their legal interpretation criteria. See Eduardo García Máynez; Introducción a la LóGica Jurídica 10 (Colofón, 2001); Galindo Sifuentes, ¿Qué es argumentar?: Retórica y lingüística, in ArgumENTACIÓN JuRídica 10-15 (Porrúa, 2011).

17 The decree modifying the name of Chapter I of Title I to 'Of Human Rights and Their Guarantees' and the amendment of various articles so as to include the scope of human rights in the Federal Constitution of Mexico was published in the Official Federal Daily Gazette on June 10, 2011. See El Derecho en México, supra note 10, at 86.

18 The doctrine upheld by Joaquin Arce and Flores-Valdes is reflected in today's Mexican legal system; see JoaQuin Arce \& Flores-Valdes El Derecho Civil-Constitucional 59-60 (Civitas, 1986).

19 Sea Miguel Acosta Romero, El fenómeno de la descodificación en el Derecho Civil, 7-8 REvista de Derecho Privado 611-628 (1989). 
grounds of any legal system, in this case, civil law, based on its fundamental institution: the individual ${ }^{20}$ set forth at both constitutional and jurisprudential levels in Mexico through the pro homine principle. ${ }^{21}$

The use of the general principles of law goes beyond cases of legal loopholes to apply to the needs of the Mexican legal system, ${ }^{22}$ with the best interests of the minor standing out as a constitutional principle.

In the field of neo-constitutionalism, principles are standards for demanding justice, ${ }^{23}$ while the rules can be binding provisions with a purely functional con-

20 Principio Pro homine. SU APLICACión. "El principio pro homine, incorporado en múltiples tratados internacionales, es un criterio hermenéutico que coincide con el rasgo fundamental de los derechos humanos, por virtud del cual debe estarse siempre a favor del hombre e implica que debe acudirse a la norma más amplia o a la interpretación extensiva cuando se trata de derechos protegidos y, por el contrario, a la norma o a la interpretación más restringida, cuando se trata de establecer límites a su ejercicio" [Pro homine principle. Its application." Incorporated into many international treaties, the pro homine principle is a hermeneutic criterion that corresponds to the fundamental feature of human rights, by virtue of which it must always be in favor of man and implies that the most comprehensive law or the most extensive interpretation must be turned to when it comes to the protection of rights and, conversely, to the most restrictive law or interpretation, when setting limits to its exercise"]. See PrinciPIo Pro homine. Su aplicación. Tribunal Colegiado de Circuito [Collegiate Circuit Court] [T.C.C.], Semanario Judicial de la Federación y su Gaceta, Novena Época, tomo XX, Octubre 2004, Tesis I.4o.A.441 A, Página 2385 (Mex).

21 See Principio pro homine. Su aplicación es Obligatoria. "El principio pro homine que implica que la interpretación jurídica siempre debe buscar el mayor beneficio para el hombre, es decir, que debe acudirse a la norma más amplia o a la interpretación extensiva cuando se trata de derechos protegidos y, por el contrario, a la norma o a la interpretación más restringida, cuando se trata de establecer límites a su ejercicio, se contempla en los artículos 29 de la Convención Americana sobre Derechos Humanos y 5 del Pacto Internacional de Derechos Civiles y Políticos, publicados en el DOF el siete y el veinte de mayo de mil novecientos ochenta y uno, respectivamente. Ahora bien, como dichos tratados forman parte de la Ley Suprema de la Unión, conforme al artículo 133 constitucional, es claro que el citado principio debe aplicarse en forma obligatoria" [Pro homine principle. Its application.] Incorporated into many international treaties, the pro homine principle is a hermeneutic criterion that corresponds to the fundamental feature of human rights, by virtue of which it must always be in favor of man and implies that the most comprehensive law or the most extensive interpretation must be turned to when it comes to the protection of rights and, conversely, to the most restrictive law or interpretation, when setting limits to its exercise, as set forth in Articles 29 of the American Convention on Human Rights and 5 of the International Covenant on Civil and Political Rights, published in the DOF on the seventh and twentieth of May one thousand nine hundred and eighty-one, respectively. However, as said treaties are part of the Supreme Law of the Union, in accordance with Article 133 of the Constitution, it is clear that the above-mentioned principle should be applied as mandatory]. See Principio Pro homine. Su aplicación es obligatoria, Tribunal Colegiado de Gircuito [Collegiate Circuit Court] [T.C.G.], Semanario Judicial de la Federación y su Gaceta, Novena Época, tomo XXI, Febrero 2005, Tesis I.4o.A.464 A, Pagina 1744 (Mex).

22 One important explanation of the general principles of law and its integrating role is given in Sergio Azúa Reyes, Los Principios Generales del Derecho 101 (Porrúa, 2007).

23 See Marco Aurelio González Maldonado, La proporcionalidad como estructura ARGUMENTATIVA DE PONDERACIÓN; UN ANÁLISIS CRÍTICO 2-3 (Novum, 2011), upholding the crite- 
tent. This is precisely what the theory of the individual and the family brings to the principles of law contained in the Mexican Constitution in the case of the best interests of the minor, which has been expressly set forth as follows:

All State decisions and actions shall ensure and comply with the principle of the best interests of the child, thus fully ensuring their rights. Boys and girls have the right to the satisfaction of their needs for food, health, education and healthy recreation for their comprehensive development. This principle should guide the design, implementation, monitoring and evaluation of public policies aimed at children. ${ }^{24}$

For years, some academics have defended State intervention in family law issues that limit the autonomy of the will in favor of the social or public rights of weaker groups. ${ }^{25}$ In this sense, the most renowned Mexican experts in civil law -in our opinion- have questioned these different positions in which the standing of the family within law which have the same characteristics as those found in social law. ${ }^{26}$ Baqueiro has also held that while it is true that the family is a social group of public interest as it is the basis of society, relationships between the members of a family are first and foremost relationships between individuals. As such, family law is rightly placed within private law. ${ }^{27}$

Under this consideration, Rogel Vide notes that it is very important to recognize the family as an institute. Its content or bases vary throughout history, and it would be better to speak of families, instead of simply family. ${ }^{28}$

ria in Robert Alexy, Los derechos fundamentales en el Estado constitucional democrático, in Neoconstitucionalismo 31-47 (Miguel Carbonell ed., Trotta, 2003).

24 See article 4, paragraph VIII of the Mexican Federal Constitution. Constitución Política de los Estados Unidos Mexicanos [Const.], as amended, art. 4, Diario Oficial de la Federación [D.O.], 5 de Febrero de 1917 (Mex).

25 Article 2 of the Civil Code of the Federal District: "La capacidad jurídica es igual para el hombre y la mujer. A ninguna persona por razón de edad, sexo, embarazo, estado civil, raza, idioma, religión, ideología, orientación sexual, identidad de género, expresión de rol de género, color de piel, nacionalidad, origen o posición social, trabajo o profesión, posición económica, carácter fisico, discapacidad o estado de salud, se le podrán negar un servicio o prestación a la que tenga derecho, ni restringir el ejercicio de sus derechos cualquiera que sea la naturaleza de éstos." [The legal capacity is equal for men and women. No person may be denied a service or benefit to which that person is entitled based on age, sex, pregnancy, civil status, race, language, religion, ideology, sexual orientation, gender identity, gender role expression, color of skin, nationality, social origin or status, work or profession, economic position, physical nature, disability or health condition, nor can the exercise of said person's rights be restricted regardless of the nature of these.], see Código Civil para el Distrito Federal [G.C.D.F.] [Civil Code of the Federal District], as amended, Diario Oficial de la Federación [D.O.], 26 de mayo de 1928 (Mex.).

${ }^{26}$ Jorge Domínguez Martínez, Derecho Givil. Parte General, Personas, cosas, negoCIO JURÍDICO E INVALIDEZ 24 (Porrúa, 2000).

27 Id.

28 Along this line of thought, see Alfonso De Cossío, II Instituciones de Derecho Civil 713 (Madrid, 1975); Carlos Rogel Vide, Derecho Civil. método y concepto 269 (ReusUbijus-Zavalia-Temis, 2010). 
The federal Mexican Judiciary has pronounced itself in favor of the distinctive quality of family proceedings. It has stated that even though controversies of a family nature are contained in civil matters at trial level, strict criteria of a civil nature should not be applied in determining the appropriateness or inappropriateness of the amparo trial subject to the principle of finality, given the importance of the individuals governed by such matters. Therefore, it should be noted that family matters and issues regarding minors and the incapacitated in particular have been the subject of repeated constitutional and legal reforms, which outline said issues as an independent field of law and feature greater protection to minors and freedom of action for the judge to intervene. The Supreme Court of Justice has acknowledged this by establishing specific principles that allow family matters to be handled with a policy of procedural simplification and of a practical nature, limited only by caution and good judgment. ${ }^{29}$

While it is possible to observe Antonio Cicu's classical assessment of acknowledging family law provisions being provisions of public order in Mexi$\mathrm{co}$, this is a false criterion to differentiate public and private law even though this does not exclude it from forming part of private law. ${ }^{30}$

In view of the intended separation of family law from civil law, it is important to recognize that the regulation of the legal personality of the individual and the attributes of the person is at the core of the law. In other words, this is essentially the right of the person known as civil law. Therefore, civil law is the right of the individual in all its manifestations for the person's fulfillment as a human being and a social being. ${ }^{31}$

We insist on the need to rescue civil law, the right of the individual and as such the following consideration seems very appropriate for the Mexican context:

The primary purpose of an individual, due to his own and indomitable individuality, is his mission to fulfill his destiny and personal purposes.

At the same time, there is a family purpose. Family renders the most elementary reality of man's coexistence, its most basic emotions. Man's life is inseparable from family reality, which the law cannot ignore and must protect. $^{32}$

29 See Definttividad. Excepción al PRINCIPIO En MATERIa FAMILIAR GUANDO El ACTO REGLAMADO OCASIONA A UN MENOR DE EDAD Un PERJUICIO DE IMPOSIBLE REPARACIÓN. Tribunal Colegiado de Circuito [Collegiate Circuit Court] [T.C.C.], Semanario Judicial de la Federación y su Gaceta, Novena Época, Libro XV, Deciembre 2012, Tesis I.3o.C.1056C, Página 1312 (Mex).

30 Antonio Cicu, cited by Castán Tobeñas, La ordenación sistemática del Derecho Civil, 105 (1954).

31 In Mexican law, Jorge Alfredo Domínguez Martinez is a staunch supporter of this position. See Domínguez, supra note 26, at 29.

32 Rogel Vide, supra note 28, at 329. 
In the Mexican judicial system, protection provided to the institution of family is legitimatized. Therefore, several legal criteria have been implemented following this line of thought, by considering that in disputes that affect the family, the family court judge can intervene ex officio and must even compensate for the parties' shortcomings in their approaches to the law because the legislators' intention was to go beyond the principle of "da mihi factum dabo tibi ius," ${ }^{33}$ under the condition that not only should inaccuracies in citing legal precepts be rectified, but an inadequate defense that could affect the family should also be avoided. ${ }^{34}$

\section{The Best Interests of the Minor: A Legal and Argumentative Framework through International Treaties and Comparative LaW}

From a legal perspective and entirely in line with the international treaties Mexico has signed, it is important to define the meaning of "minor." legal perspective also implies a social dimension, which is aptly stated in national and foreign doctrine. ${ }^{36}$ It is also essential to differentiate the minor from a person declared incompetent because the minor is subject and object of all a person's inherent rights, dignity and present and future fulfillment. Therein lays the principle of the best interests of the minor in terms of both content and purpose. ${ }^{37}$

In the Mexican legal system, international agreements are a source of law, specifically and based on Article 133 of the Mexican Constitution. ${ }^{38}$ Accord-

33 Give me the facts that I will give the law.

34 See Derecho de familia. Suplencia de los planteamientos de Derecho, conforme

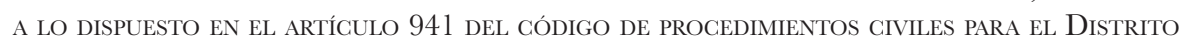
Federal, Tribunal Colegiado de Circuito [T.G.G.] [Collegiate Circuit Court], Semanario Judicial de la Federación y su Gaceta, Novena Época, tomo XXXII, Octubre 2010, Tesis I.3o.C.850C, Página 2986 (Mex).

35 Nuria González Martín, Familia internacional en México: adopción, alimentos, SUSTRACGión, TRÁFICO Y TRATA 71 (UNAM-Porrúa, 2009).

36 For example, Rivero Hernández holds that (a) the child is, first and foremost, a person, in its most essential and transcendent sense and not only in its legal dimension (a holder of rights), but also in its human dimension (a being that feels and thinks); (b) in addition, [the child] is a human reality in the making because his evolution (his future) is more important than only his current reality. If everything and everyone changes over time, this is more noticeable and, especially more important in [the case of] a minor, for whom every day of life leads him nearer to cease being [a minor], reaching the age of majority and the legal status to which he aspires. See Rivero Hernández, El interés del menor, Dykinson 56 (2007).

37 Regarding its international scope on the definition of minors, Advisory Opinion on status and human rights of children, OG-17/2002 Inter-Am. Ct.H.R. (Aug. 28 2002) states that "For the aims sought by this Advisory Opinion, the difference established between those over and under 18 will suffice. [...] Adulthood brings with it the possibility of fully exercising rights, also known as the capacity to act."

38 Article 133 of Mexican Constitution states that "esta Constitución, las leyes del Con- 
Esta revista forma parte del acervo de la Biblioteca Jurídica Virtual del Instituto de Investigaciones Jurídicas de la UNAM www.juridicas.unam.mx

ing to jurisprudence, international treaties have been positioned at an infraconstitucional, but supralegal level, which gives importance to ratified international agreements on this issue.

Mexico has signed important international instruments on the protection of minors. For the purposes of this paper, the following documents will be highlighted:

- Convention on the Rights of the Child. ${ }^{39}$ The Convention recalls that in the Universal Declaration of Human Rights, the United Nations proclaimed that childhood is entitled to special care and assistance.

- The 1969 American Convention (Pact of San José). In the legal political system of the Americas, the Organization of American States (OAS) stands out as a human rights protection agency. It has a jurisdictional supervisory body, the Inter-American Court of Human Rights. ${ }^{40}$ The Convention is notable for its dual recognition of human rights, or as by some authors, rights for all and specific rights, which include children, youth or minors. ${ }^{41}$

- Inter-American Court of Human Rights. The Inter-American Court is an autonomous judicial OAS institution. Its goal is the implementation and interpretation of the American Convention on Human Rights and other treaties on the same subject. Established in 1979, it is formed of jurists of the highest moral authority and recognized competence in the field of human rights elected for their personal capacity.

greso de la Unión que emanen de ella y todos los tratados que estén de acuerdo con la misma, celebrados y que se celebren por el presidente de la República, con aprobación del senado, serán la ley suprema de toda la Unión. Los jueces de cada estado se arreglarán a dicha Constitución, leyes y tratados, a pesar de las disposiciones en contrario que pueda haber en las constituciones o leyes de los estados" ["This Constitution, the laws of the Congress of the Union that come from it, and all the treaties that are in accord with it, that have been concluded and that are to be concluded by the President of the Republic with approval of the Senate will be the Supreme Law of all the Union. The judges of every State will follow this Constitution and these laws and treaties in considering dispositions to the contrary that are contained in the constitutions or laws of the States."]. See Constitución Política de los Estados Unidos Mexicanos [Const.], as amended, art. 133 Diario Oficial de la Federación [D.O.], 5 de Febrero de 1917 (Mex).

39 Adopted and opened for signature and ratification by the General Assembly in its Resolution 44/25 of 20 November 1989, passed by the Senate on 19 June 1990, as published in the DOF on 31 July 1990. The order for its enactment was published in the Diario Oficial de la Federación [D.O.F.] on January 25, 1991.

40 Mexico recognizes the Inter-American Court and is subject to its competence and jurisdiction on ratifying the American Convention on Human Rights. Mexico also recognized the contentious jurisdiction of the Inter-American Court through a statement from the Government of Mexico dated December 16, 1998.

41 Nuria GonzÁlez Martin \& Sonia Rodríguez Jiménez, El interés SUPerior del MeNOR EN EL MARCO DE LA ADOPCiÓN Y EL TRÁFICO INTERNACIONAL, CONTEXTO MEXICANO 71 (Instituto de Investigaciones Jurídicas, UNAM, 2011). 
There are other international instruments that comprise the Inter-American system for the human rights of children and adolescents, including:

1) Inter-American Convention on Conflict of Laws Concerning the Adoption of Minors (OAS, May 25, 1984). ${ }^{42}$

2) Inter-American Convention on the International Return of Minors (OAS, July 15, 1989). ${ }^{43}$

3) Inter-American Convention on Support Obligations (OAS, May 24, 1984). ${ }^{44}$

\section{Comparative Law}

European countries with a Romano-Germanic legal system, such as Spain, recognize the right of youth and children to protection as being vulnerable groups. In order to balance the right to inform and the rights of the child, Directive 2/2006 from State Attorney General's Office in Spain, it should be assumed that the dissemination of accurate information of public interest is justified even though it may affect a minor, provided that it does not go against his interests or that his anonymity is guaranteed. This directive imposes certain requirements or procedures: If a minor appears in the media, the public prosecutor must have knowledge of it. Although this premise is rarely complied with, the violation of a minor's rights of legal personality are prosecutable ex officio. ${ }^{45}$

The Handbook for Professionals and Policymakers on Justice in Matters involving Child Victims and Witnesses of Crime for professionals and policy makers ${ }^{46}$ recommends steps to be taken to protect minors in such cases. Reference to these international guidelines is very important because a minor's right to privacy and to the protection of his image and identity are consistent-

42 This convention was ratified by Mexico on June 12, 1987, to enter into force on May 26, 1988.

43 This convention was ratified by Mexico on October 5, 1994, to enter into force in Mexico on November 4, 1994.

44 This convention entered into force in Mexico on May 26, 1988. Mexico issued the following interpretative declaration: "The Government of Mexico declares, in accordance with Article 3 of the Convention, that it recognizes as support creditors, in addition to those indicated, concubines, collateral kinsmen, such as minors or incompetent persons up to the fourth degree and the adopted in relation to the adopter. The obligation to give support is reciprocal. The person giving such support in turn has the right to request it."

45 Directive 2/2006 from State Attorney General's Office (Spain), on the Public Prosecutor and the Protection of the Child's Right to Honor, Privacy and Self-Image (March 15 2006).

46 Handbook for Professionals and Policymakers on Fustice in Matters involving Child Victims and Witnesses of Crime, United Nations Office on Drugs and Crime, Criminal Justice Handbook Series, New York, 2010. 
ly violated by the Mexican media, especially in the southeastern region of the country. This handbook clearly stipulates what should be done in such cases. ${ }^{47}$

When a child suffers because inappropriate information about his image and private life was made public, especially by the media, several future hypothetical scenarios can occur, none of which are good. First of all, the child is at risk. Similar cases took place in the State of Tabasco, in February 2010, when information was released about a military serviceman's family and the children living in that house were murdered.

Secondly, the child may experience extreme embarrassment in his social setting that will cause him to suffer humiliation or later being singled out. These situations will not only repress communication, but also aggressive attitudes in the future. ${ }^{48}$

In comparative law research on the issue of child protection based on the best interests of the child, we observe a void in child protection in the case of due process of law and in media practices. The solution provided in the Handbook on how to implement the guidelines on justice is of utmost importance since it considers judges, ${ }^{49}$ civil servants, lawyers, legislators and especially the media as actors with obligations. The Handbook also includes the organizations that allow for minors to be protected in the case of violations caused by the media, by raising awareness on the role and responsibility of the media with regard to the rights of children.

47 The Handbook highlights the specific recommendations set out in the Guidelines on Justice in Matters involving Child Victims and Witnesses of Crime (Chapter X, The Right to Privacy): "26. Child victims and witnesses should have their privacy protected as a matter of primary importance. 27. Information relating to a child's involvement in the justice process should be protected. This can be achieved through maintaining confidentiality and restricting disclosure of information that may lead to the identification of a child who is a victim or witness in the justice process. 28. Measures should be taken to protect children from undue exposure to the public by, for example, excluding the public and the media from the courtroom during the child's testimony, where permitted by national law."

48 A measure to prevent such situations, we find for example in the article 8 paragraph e) of the Optional Protocol to the Convention on the Rights of the Child on the sale of children, child prostitution and child pornography states that necessary measures to protect the privacy and identity of children should be adopted.

49 Judges: respecting the confidentiality of information on child victims and witnesses of crime; where necessary to safeguard the privacy of child victims or witnesses, ordering the full exclusion of the public and in camera proceedings; Law enforcement officials: respecting the confidentiality of information on child victims and witnesses of crime; in particular, refraining from disclosing such information to anyone without prior authorization; Lawyers: respecting the confidentiality of information on child victims and witnesses of crime; in particular, refraining from disclosing such information to anyone without prior authorization; requesting measures for the protection of the identity of the child victim or witness, in case these measures do not automatically apply; Media: adopting and respecting self-regulation measures to protect the privacy and personal data of a victim; [...]. See Handbook for Professionals and Policymakers on Fustice in matters involving child victims and witnesses of crime, supra note 46, at 62. 
The violation of human dignity as a principle and the content of human rights has legal consequences defined in the Handbook, which establishes a type of moral damage as found in the Spanish-Mexican system. ${ }^{50}$

The way the legal protection of minors is handled in terms of the information disclosed by the media is especially important in the north and center regions of Mexico. With regard to southern Mexico, as a case in question, we point at the State of Tabasco where its constitution was amended in September $2013^{51}$ to include a list of human rights that coincides with those contained in the Federal Constitution and the American Convention on Human Rights. Furthermore, Tabasco has implemented special laws such as the Law for the Protection of the Rights of Children and Adolescents ${ }^{52}$ in which the state executive branch controls the information that goes against or violates the principles of peace, non-discrimination and respect to all people, as well as any information that promotes violence towards or advocates criminal acts against minors. However, there are no precautionary measures or procedural mechanisms that objectively weigh the work of the media in the State of Tabasco so as to determine the behaviors that contravene the rights of minors and the applicable penalties. We took a sampling of the four most important newspapers with the largest circulation in the State of Tabasco, as well as two tabloids associated with the chosen newspapers and known for their sensationalist news. In a 6-month period that analyzed 716 newspaper issues, we found that 126 contained articles that affected the rights of the youth to legal personality, such as: personality rights, the right to honor, privacy and the presumption of innocence.

The study showed that young people are increasingly being represented as problems. It seems that children in conflict with the law are no longer considered children. It is as if a breach with the law excludes them from exercising their right to the protection as children. To be dealt with in exactly the same way as adult perpetrators or, worse, to abuse their vulnerability as children is detrimental to their overall psyche. For example, one of the articles in question proves the effects on the rights to honor, privacy and the presumption of innocence. This particular article displayed a headline that read "the devil's kids" [chamacos del demonio] to report on two 16-year-olds who were arrested for driving in the opposite direction and third degree driving while under the

50 Chapter 10: The right to reparation. Guidelines on Justice in Matters involving Child Victims and Witnesses of Crime, chapter XIII, The right to reparation 35. Child victims should, wherever possible, receive reparation in order to achieve full redress, reintegration and recovery. Procedures for obtaining and enforcing reparation should be readily accessible and child-sensitive. In this regard, see $i d$. at 95.

51 Political Constitution of the Free and Sovereign State of Tabasco, published through a solemn proclamation on April 5, 1919, with its latest reforms published in the Official State Gazette on June 21, 2014.

${ }^{52}$ Ley para la Protección de los Derechos de Niñas, Niños y Adolescentes [Law for the Protection of the Rights of Children and Adolescents], Periódico Oficial del Estado [P.O.E.] [State Official Gazette] 3 de Enero de 2007 (Mex.). 
Esta revista forma parte del acervo de la Biblioteca Jurídica Virtual del Instituto de Investigaciones Jurídicas de la UNAM www.juridicas.unam. $m x$

influence of alcohol. The newspaper also published their full names and that of the "judge" handling the case. The irresponsibility of this type of reporting was made apparent when the young people implicated were beaten by highway agents.

In some states of Mexico, as seen in the case taking place in Tabasco, a child's rights may be violated by the media in a number of ways through inappropriate exposure and stereotypes. The media's social responsibility should look after the welfare of minors and not focus on negative role models. Otherwise, it is the child who is harmed the most. Moreover, the nature of the freedom of expression as a means to disseminate information of public interest is lost. It identifies a system of responsibility as a type of mechanism used to ensure that the media is socially responsible - as an inducement for the media and journalists to respect the ethical standards established by the profession and the new legal models.

In weighting the exercise of freedom of expression after the analysis of four Tabasco state newspapers, which include those with the largest circulation, the following was observed: (a) coverage of issues relating to children tends to focus on the negative and sensationalist aspects of the activities of said children; (b) reports about children are not usual and contain no further analysis or follow-up; and (c) respect for confidentiality involving information on children or protecting the principle of presumption of innocence is not perceived.

The way the legal protection of minors is handled in terms of the information disclosed by the media - in spite of signing international treaties on the matter - has not been able to penetrate this fundamental fact of its application of the best interests of the child. We will now go on to explain the main human rights regulations in force in Mexico.

\section{Domestic Legal Framework}

The political Constitution of the United Mexican States recognizes and protects human rights, including:

- Right to education.

- Right to a family.

- Right to preferential health care.

- Right to not be forced to work.

- The right to adequate food.

With the constitutional reform in 2000 the rights of children and youth rose to the level of constitutional status. Some amendments are:

- The concept of "child" is incorporated in an effort to gradually replace the term "minor". It establishes the State's obligation to provide what is necessary for the respect of the dignity of children and the effective- 
ness in their exercise of these rights. It also takes into account the duty of parents and guardians to preserve such rights.

In 2001, important reforms were made to the Constitution. Article 1 establishes the prohibition of any form of discrimination. Meanwhile, the constitutional reform of June 10, 2011 replaced the term "individual guarantees" in the Mexican Constitution with "human rights", thus incorporating the rights contained in the international human rights treaties to which Mexico is a State party. This means that the group of internationally recognized rights and obligations now form part of the national legal system, which in turn implies the application of the principles of pro persona or of conforming interpretation. According to the content of Article 1 of the Constitution, it must be understood that the Convention on the Rights of the Child is an internal law, so the rights of children and adolescents were expanded as of June 10, 2011.

Lastly, after the constitutional reform regarding human rights on October 12, 2011, the reform to Article 4 of the Mexican Constitution was approved. This article embodies the principle of the best interests of the child, as well as its incorporation into Mexican government policies. Both the Federal Congress and local congresses can legislate on the matter under the terms of Article 4 of the Mexican constitution, Article 3 of the Convention on the Rights of the Child - ratified by Mexico and published in the Federal Official Gazette on January 25, 1991 - and Articles 3, 4, 6 and 7 of the Law for the Protection of the Rights of Children and Adolescents.

However, the term "best interests of the child" is undoubtedly still an open clause and it is the court that must equitably and not arbitrarily define the contents of such principle. In this regard, the Federal Judicial Branch has proclaimed that "the expression 'best interests of the child' [...] implies that the child's development and full exercise of his rights should be considered criteria governing the drafting of standards and their application in all aspects related to the life of the child." ${ }^{53}$

The Mexican legal system establishes various prerogatives of a personal and social nature in favor of minors, which are reflected in both the constitution and international treaties, as well as in federal and local laws, where it is implied that the best interests of the child means that policies, actions and decisions related to this stage of the human life must at all times be upheld in a way that strives to ensure the direct benefit of the child to whom they are directed. ${ }^{54}$

53 Judicial Opinion issued by the First Chamber, see Derechos Derivados DE LA PATRIA potestad (Código Givil del Estado de México), Suprema Corte de Justicia [S.C.J.N.] [Supreme Court of Justice], Semanario Judicial de la Federación y su Gaceta, Novena Época, tomo XXVIII, Diciembre 2008, Tesis 1st. CXI/2008, Página 236 (Mex).

54 See Interés Superior del Menor. Alcances de este Principio, Tribunal Colegiado de 
The civil laws in the various Mexican states have been adapted to expressly include the principle of the best interests of the child in their local legislations. ${ }^{55}$

\section{Law for the Protection of the Rights of Children and Adolescents}

The law ${ }^{56}$ is based on the sixth paragraph of Article 4 of the Mexican Constitution. Its provisions are of ordre public, social interest and general ob-

Circuito [T.C.C.] [Collegiate Circuit Court], Semanario Judicial de la Federación y su Gaceta, Novena Época, tomo XXXIII, Marzo 2011, Tesis I.5th.G.J/14, Página 2187 (Mex).

55 For example, in article 404 repealed in April 2013 of Federal Civil Code: "La adopción simple podrá convertirse en plena, debiendo obtenerse el consentimiento del adoptado, si éste hubiere cumplido doce años. Si fuere menor de esa edad se requiere el consentimiento de quien hubiese consentido en la adopción, siempre y cuando sea posible obtenerlo; de lo contrario el juez deberá resolver atendiendo al interés superior del menor.

En este supuesto, con base en el interés superior del menor, éste quedará bajo los cuidados y atenciones de uno de ellos. El otro estará obligado a colaborar en su alimentación y conservará los derechos de vigilancia y de convivencia con el menor, conforme a las modalidades previstas en el convenio o resolución judicial."

[A simple adoption may be fulfilled, having obtained the adoptee's consent, if the adoptee has reached the age of twelve. If the adoptee is under this age, the consent of whoever had consented to the adoption is required, provided it is possible to obtain said consent; otherwise, the judge must decide based on the best interests of the child.

In this case, based on the best interests of the minor, the minor shall remain under the care and attention of one of them. The other is obligated to contribute to the minor's sustenance and will retain the rights of supervision and of coexistence with the minor, according to the provisions set forth in the legal agreement or judgment.] See Código Civil Federal [C.C.F.] [Federal Civil Code], as amended, Diario Oficial de la Federación [D.O.], 26 de Mayo de 1928 (Mex).

See also Article 416. "En caso de separación de quienes ejercen la patria potestad, ambos deberán continuar con el cumplimiento de sus deberes y podrán convenir los términos de su ejercicio, particularmente en lo relativo a la guarda y custodia de los menores. En caso de desacuerdo, el juez de lo familiar resolverá lo conducente oyendo al Ministerio Público, sin perjuicio de lo previsto en el artículo 94 del Código de Procedimientos Civiles para el Distrito Federal. En este supuesto, con base en el interés superior del menor, éste quedará bajo los cuidados y atenciones de uno de ellos. El otro estará obligado a colaborar en su alimentación y conservará los derechos de vigilancia y de convivencia con el menor, conforme a las modalidades previstas en el convenio o resolución judicial".

In the event of the separation of those exercising parental authority, both must continue to fulfill their duties and may agree to the terms of its exercise, particularly with regard to the guardianship and custody of the minors. In the case of a disagreement, the family court judge shall decide on the matter, listening to the Public Prosecutor, without contravening that set forth in Article 94 of the Code of Civil Procedure for the Federal District. In this case, based on the best interests of the minor, the minor shall remain under the care and attention of one of them. The other is obligated to contribute to the minor's sustenance and shall retain the rights of supervision and of coexistence with the minor, according to the provisions set forth in the legal agreement or judgment]. See Código Civil Federal [C.C.F.] [Federal Civil Code], as amended, Diario Oficial de la Federación [D.O.], 26 de Mayo de 1928 (Mex).

56 Ley para la Protección de los Derechos de Niñas, Niños y Adolescentes [Law for the 
servance in all of Mexico. Its aim is to ensure the protection of children and adolescents and the respect of their fundamental rights as recognized in the Constitution.

The law uses inclusive language to define the concept of boy and girl. ${ }^{57}$ The protection of the rights of children and adolescents aims at ensuring them full and comprehensive development, which implies the opportunity to develop physically, mentally, emotionally, socially and morally in conditions of equality.

The guiding principles for the protection of the rights of children and adolescents are:

a) The best interests of the child.

b) The principle non-discrimination for any reason or circumstance.

c) Equality without distinction of race, age, sex, religion, language, political or other opinion, ethnic, national or social origin, economic standing, disability, circumstances of birth or any other condition of his or his parents, guardians or legal representatives.

d) The right to live in a family, as an essential space for development.

e) The right to have a life free of violence.

f) Shared duties among the members of the family, the State and society.

g) The full and equal exercise of human rights and constitutional guarantees..$^{58}$

The law also defines the content of the principle of the best interests of the child. It states that the rules applicable to children and adolescents are to be understood as aimed at securing for them principally the care and assistance they need to achieve their full growth and development within a safe environment of family and social well-being. According to this principle, the exercise of adults' rights may not, at any time or under any circumstance, supersede the exercise of the rights of children and adolescents.

The general principles will be specifically applied in the absence of an express provision in the Constitution, this law or international treaties under the terms of Article 133 of the Constitution.

\section{The Best Interests of the Child: Weighting as an Argumentation Framework}

The explanation about the evolution of the general principles of civil law to fundamental rights has recently been established by the Supreme Court of

Protection of the Rights of Children and Adolescents] [L.P.D.N.A.], Diario Oficial de la Federación [D.O.] 29 de Mayo del 2000 (Mex)

57 See Id. at art. 2. "Para los efectos de esta ley, son niñas y niños las personas de hasta 12 años incompletos, y adolescentes los que tienen entre 12 años cumplidos y 18 años incumplidos" [For the purposes of this law, people under the age of 12 are [considered] children, and teenagers are those between the ages of 12 and 18]..

58 See Id. at art. 3. 
Justice in a sentence of a jurisprudential nature. In summary, this sentence laid down the following:

The classical formulation of fundamental rights as limits directed solely at public authorities has proven insufficient to respond to the violations of those rights through acts carried out by individuals. In this sense, it is undeniable that relationships of inequality that are found in contemporary societies and establish privileged positions for one party can lead to the possible violation of fundamental rights at the expense of the weakest party. The Political Constitution of the United Mexican States offers no textual foundation that allows the assertion or denial of the validity of fundamental rights among individuals. However, this is not an insurmountable impediment, because in order to give an adequate response to this issue, it should start from the specific examination of the norm of fundamental right and those characteristics that determine their function, scope and development within the legal system. Thus, it is necessary to examine, first, the tasks that comply with the fundamental rights in the legal system. In the opinion of this First Chamber, the fundamental rights set forth in the Constitution are two-fold because on the one hand, they are established as subjective public rights (subjective function) and on the other hand they are translated into objective elements which inform or permeate the entire legal system, including those that arise between individuals (objective function). In a legal system like ours - in which constitutional provisions constitute the Supreme Law of the Union - fundamental rights occupy a central and undisputed position as the minimum content of all legal relationships that occur in the law. Along this line of thought, the dual role fundamental rights play in the regulation and structure of certain rights form the basis that makes it possible to affirm its occurrence in dealings between individuals. However, it is important to highlight that upholding fundamental rights in relations between individuals cannot be sustained as dominant and in its totality in each and every one of the relationships that occur in accordance with private law in virtue of the fact that in these relation, unlike those involving the State, we usually find another holder of rights, which causes a conflict of these rights and necessary weighting by the interpreter. Thus, the fundamental task of the interpreter is to analyze, in a unique way, the legal relations in which fundamental rights often come up against other goods or constitutionally protected rights; at the same time, the structure and content of each right will make it possible to determine what rights are only enforceable against the State and what other rights enjoy purported multi-directionality. ${ }^{59}$

According to the ways in which the constitutionalization of civil law operates, three paths are discussed: legal reform, constitutional interpretation and the weighting of constitutional principles in the case of conflicts between

59 See Derechos fundamentales. Su vigencia en las Relaciones entre particulares, Primera Sala de la Suprema Corte de Justicia de la nación [S.C.J.N.] [First Chamber of the Supreme Court of Justice], Semanario Judicial de la Federación y su Gaceta, Décima Época, tomo XIII, Octubre 2012, Tesis 1st./J. 15/2012, Página 798 (Mex). 
individuals. ${ }^{60}$ However, the legislative gaps in the occurrence of conflicts between individuals must be specifically resolved through weighting techniques carried out by judges on the basis of judicial interpretation and the principle pro homine, which highlights the best interests of the child in the theory of the protection of the right to personality. It is the exercise of fundamental rights in dealings between individuals that cannot be understood because its hegemonic form cannot be overlooked as a role of the nuclear law and common civil law in terms of private law in general and of the entire legal system.

The following section explains how the highest Mexican judicial body has weighted issues according to principles or fundamental rights which include the best interests of the child.

\section{Gase Studies from Mexican Jurisprudence}

As seen, the best interests of the child have ceased to have a void in its content in terms of principle. The Supreme Court of Justice rulings on cases are shaping new content that will serve as a weighted judgment. However, the protection of minors and their rights of personality has not yet been an issue to be decided on by the highest judicial authority in Mexico, nor has it been addressed in courts of different States. In our view as researchers, a declaration must soon be made on this issue due to its importance in the country and based on the cases which have given new meaning to the best interests of the child over other human rights in Mexican courts.

\section{Balancing between the Rights of Privacy of Minors and the Right to Expert Evidence} Presented by the Opposing Party

If at a trial a ruling that might affect the interest of the minor is issued, such as the expert in the field of gynecology that which must necessarily take place prior to the physical examination of a teenage minor, it is clear that this a fact that it can affect the rights to intimacy and privacy. Thus, in these cases, first rights, along with those of the audience, enshrined in the Constitution must be respected regarding minors and according to the principle of the best interests of the minor. ${ }^{61}$

60 See Hernán Corral Talciani, Algunas reflexiones sobre la constitucionalización DEL DERECHO PRIVAdo 3 (2004) available at http://corraltalciani.files.wordpress.com/2010/05/ constitucionalizaciond-privado.pdf

61 See Derechos de privacía e intimidad de menores de edad. Previamente a la admisIÓN DE PRUEBaS EN JUICIO QUE PUEDAN AFECTARLOS, DEBE DÁRSELES VISTA PARA QUE EXPRESEN LO conducente como parte interesada, Tribunal Colegiado de Circuito [T.C.C.] [Collegiate Circuit Court], Semanario Judicial de la Federación y su Gaceta, Novena Época, tomo XXII, Noviembre 2005, Tesis II.2o.C.502 C, Página 860 (Mex). 
Esta revista forma parte del acervo de la Biblioteca Jurídica Virtual del Instituto de Investigaciones Jurídicas de la UNAM www.juridicas.unam. $m x$

\section{Principle of Equality between Men and Women and the Minor's Right to Sustenance}

The Mexican Supreme Court of Justice has not only determined what should be understood by the principle of equality ("the constitutional requirement to give equal treatment to those who are equal and unequal treatment to those that are unequal, so that the distinction that are sometimes made will be forbidden, while in other cases it will be allowed, or even required constitutionally"), but has also decided on a set of criteria to complement the scope of this principle, as well as to define when a distinction or preference set by legislators between two similar cases are justified without constituting an act of discrimination and when it is considered unjustified and therefore implies discrimination.

On these grounds and according to the provisions of Article 303 of the Civil Code for the Federal District, both parents are obligated to fulfill the requirements of providing the food that the minor needs. The best interests of the minor are above the rights of both parents. Thus, this burden is not only imposed upon the man, but it also falls on the woman. Therefore, the fact that a procedural obligation is imposed on one of the parents to provide a certain percentage of their salary for his or her child's sustenance, despite earning less than his or her counterpart, it is not a case of discrimination due to gender, nor does it violate the principle of equality. According to Article 309 of the aforementioned code, the specific way of fulfilling this obligation is that when the child forms part of the mother's household, the mother must provide the items not covered by the amount set for the father to pay. If both parents have jobs and earn an income, they have the obligation to contribute, to the extent of their possibilities, to that which is necessary for the survival of the child. ${ }^{62}$

\section{Content and Scope of the Minor's Right to Identity Based on the Best Interests of the Minor}

Article 7 of the Convention on the Rights of the Child (ratified by Mexico and published in the DOF on January 25, 1991) establishes that the child has the right from the birth to a name, to acquire a nationality and, as far as possible, to know and be cared for by his or her parents. In keeping with the above article and paragraph 3 of the Law for the Protection of the Rights of Children and Adolescents (of ordre public, social interest and general observance in all of Mexico), the guiding principles for the protection of minors are the best interests of the child and the protection of the full and equal

62 See Igualdad del hombre y la mujer y NO DISCRIMINACión POR RAZONES DE GÉNERO. SON PRINCIPIOS QUE NO SE VIOLAN GUANDO SE INVOLUCRA EL DERECHO DE UN MENOR A RECIBIR alimentos de ambos progenitores, Tribunal Colegiado de Circuito [T.C.C.] [Collegiate Circuit Court], Semanario Judicial de la Federación y su Gaceta, Novena Época, tomo XXXIII, Marzo 2011, Tesis I.14o.C.77 C, Página 2355 (Mex). 
enjoyment of human rights and constitutional guarantees, among others. On the same note, Article 22 of the above law establishes the right to an identity, which consists of the right to have a name and the surnames of parents as of the moment of the child's birth, to have a nationality and to know his parentage and his origin, except in cases where the law prohibits it. The fact that the minor has the certainty of who his parent are is a principle of ordre public that is part of the nucleus of the fundamental right to legal personality. The importance of this does not only lie in the ability to request and receive information about his origin, the identity of his parents and knowledge of his genetic origin, but these elements can also lead to fulfilling his right to a nationality on one hand, and the right to have his ascendants satisfy his needs of sustenance, health, education and healthy recreation for his full and comprehensive development. ${ }^{63}$

\section{The Minor's Right to an Identity and the Very Personal Act of Acknowledging Parentage}

In accordance with the Mexican Constitution, various international standards and other domestic law statutes that enshrine the principle of the best interests of the minor and because the regime of rights is a genuine protectionist system, the child has the right to preserve his identity, name and family relations, as well as to be provided with assistance and care when he is deprived of any of the elements of identity so it can be restored immediately to the child.

Hence, the voluntary acknowledgment of a child as one's own before an official at Civil Registry is a very personal legal act. Through this proceeding, the person appearing and the person being acknowledged acquire all the rights and obligations attributed to parentage. Given that the law does not require the alleged father to undergo paternity testing in order to acknowledge a minor, it is feasible to do so, both in the case in which there are no blood ties (like when there is doubt) and even when there are sufficient elements that give certainty that the person to be acknowledged is the true descendant of the acknowledging party. Thus, any action revoking acknowledged parentage on a birth certificate of a child born outside wedlock is procedurally irrelevant; when the intention is to contest such acknowledgement, the legal act must be ruled null and void since the lack of a biological link is not enough evidence.

In these cases, it is essential to accredit the nullity of the acknowledgement; that is, the lack of a real declaration of paternity issued by a person with the capacity required by law or circumstances at the time that were the result of

63 See Derecho a la identidad de los menores. Su contenido, Primera Sala de la Suprema Corte de Justicia de la nación [S.C.J.N.] [First Chamber of the Supreme Court of Justice] Semanario Judicial de la Federación y su Gaceta, Novena Época, tomo XXVI, Julio 2007, Tesis 1st. CXLII/2007, Página 260 (Mex). 
error, deception, physical violence and intimidation. This procedure basically consists of informing the Civil Registry Office of the defect in consent at the time of acknowledging the child.

The above does not contradict the principle of irrevocability of the acknowledgement of a child. Just as with any other legal act, this proceeding may be subject to annulment. However, an annulment granted by court ruling should not be confused with a revocation of the acknowledgement by way of withdrawal. ${ }^{64}$

\section{The Minor's Right to an Identity and the Rights Derived from the Concept of Family}

The Constitution protects certain goods and supreme inalienable values, including the protection of the organization and the development of the family. However, the article 4o of the Constitution establishes the rights of children on equal standing, as seen in paragraphs 5, 6 and 7, which state that "children have rights, which include, that the State must provide what is necessary to promote respect for the dignity of children and the full exercise of their rights". This makes it apparent that the Constitution establishes a single normative hierarchy for the protection of both the family and the child. In this context, in the weighting of the stated values (that is, balancing or counterbalancing one right with another), the right of children to know their true identity has greater weight because the possibility of knowing their exact genetic origin gives them certainty as to their true ancestry. This is a psychological and emotional benefit because knowing who their real parents are awakens a feeling of confidence, moral support and belonging towards his real family in knowing that he is protected and being brought up by his real parents. Ultimately, this benefits the child more than the alleged protection to the household under the intention of unduly forcing family unity by trying to preserve said ties even when it is apparent that one or several members are under the suspicion of not having genuine familial bonds.

Therefore, according to the national and international laws that give priority to the best interests of the minor, the protection of the rights of the child deserves greater protection because it is the weaker party in the concept of the family, and it is the child who may suffer greater damage depending on the measure to be implemented. Therefore, when a judge is faced with the need to weigh constitutional values of the same category (i.e., choosing between protecting the family and the child's right to know his true parentage), the first must yield with respect to the latter. ${ }^{65}$

64 See Revocación de filiación de hijo nacido fuera de matrimonio. Previamente a DEMANDARLA, DEBE IMPUGNARSE LA NULIDAD DEL REGONOCIMIENTO EFECTUADO EN LA PARTIDA DE nacimiento, Tribunal Colegiado de Circuito [T.C.C.] [Collegiate Circuit Court], Semanario Judicial de la Federación y su Gaceta, Novena Época, tomo XXXII, Agosto 2010, Tesis III.2o.C.183 C, Página 2358 (Mex).

65 See Menores de edad. El Derecho para conocer su origen genético constituye un 


\section{The Right of Paternity and the Right to an Identity ${ }^{66}$}

When the alleged parents refuse to undergo genetic testing, it gives way to the assumption of controversial parentage. As long as the corresponding court based its decision on an analogical interpretation and the general principles of law, it was conceivable to assume said parentage. With that assumption, the Mexican judiciary specifically estimates that it is possible to reach this conclusion through civil legislation, taking into account this kind of legal interpretation, as well as the exact application of Article 4 of the Constitution; Articles 3, 6, 7 and 8 of the Convention on the Rights of the Child and Article 22 of the Law for the Protection of the Rights of Children and Adolescents. Therefore, if these provisions indicate the right of the child to know his identity and that the importance of this fundamental right lies not only in the possibility of learning his biological origin (ancestry), but that this knowledge leads to the fulfillment of a child's constitutionally established right to have his ascendants satisfy his needs of sustenance, health, education and healthy recreation for his comprehensive development, which may involve the right to a particular nationality.

On the other hand, the Code of Civil Procedure establishes enforcement measures through which judges can ensure that their judgments are fulfilled. When in a paternity lawsuit the judge orders DNA testing and the presumed parent refuses to be tested, the abovementioned measures can constitutionally be applied to comply with the judge's directive. However, if it is not possible to overcome the parent's refusal to undergo testing by means of said measures, this does not mean that the best interests of the child should be at the mercy of the presumed parent, and that such refusal or opposition to the testing go without any legal consequences. In every case, the assumption of controversial parentage should apply. Although the laws of the State of Veracruz do not contain a provision that expressly requires it, the best interests

BIEN JURÍDICO CONSTITUCIONALMENTE LEGÍTIMO CON MAYOR RELEVANCIA FRENTE A LOS DERECHOS Derivados del concepto de familia, Tribunal Colegiado de Circuito [T.C.C.] [Collegiate Circuit Court], Semanario Judicial de la Federación y su Gaceta, Novena Época, tomo XXX, Agosto2009, Tesis I.10o.C.73 C, Página 1661 (Mex).

66 See Juicios de Paternidad. En los Casos EN QUe a PESAR DE LA IMPOSICIÓN DE MEDIDAS DE APREMIO LOS PRESUNTOS ASCENDIENTES SE NIEGAN A PRACTICARSE LA PRUEBA PERICIAL EN MATERIA DE GENÉTICA (ADN), OPERA LA PRESUNCIÓN DE LA FILIACIÓN CONTROVERTIDA, SALVO PRUEBA EN Contrario, Tribunal Colegiado de Circuito [T.C.C.] [Collegiate Circuit Court], Semanario Judicial de la Federación y su Gaceta, Novena Época, tomo XXVII, Febrero 2008, Tesis VII.2o.C.111G, Página 2313 (Mex). See also Juicios de Paternidad. En los Casos en Que A PESAR DE LA IMPOSICIÓN DE MEDIDAS DE APREMIO LOS PRESUNTOS ASCENDIENTES SE NIEGAN A PRACTICARSE LA PRUEBA PERICIAL EN MATERIA DE GENÉTICA (ADN), OPERA LA PRESUNCIÓN DE LA FILIACIÓN COntrovertida (Legislaciones de nuevo león y del estado De MéXico), Primera Sala de la Suprema Corte de Justicia de la nación [S.C.J.N.] [First Chamber of the Supreme Court of Justice] Semanario Judicial de la Federación y su Gaceta, Novena Época, tomo XXV, Marzo 2007, Tesis 1a./J. 101/2006, Página 111, (Mex). 
Esta revista forma parte del acervo de la Biblioteca Jurídica Virtual del Instituto de Investigaciones Jurídicas de la UNAM www.juridicas.unam. $m x$

of the child and an extensive analogous interpretation of Article 257 of the Code of Civil Procedures, which establishes the assumption of tacit confession, should be taken into account. Thus, it can be concluded that in the event of the presumed parent's refusal to undergo this testing the assumption of parentage applies, unless there is a test or law to the contrary; otherwise, the best interests of the child would be at the mercy of the presumed alleged parent and the child's their fundamental right to know his heir identity would not be respected.

\section{A Child's Right to Express His Opinion in the Jurisdictional Procedures that Affect His Legal Sphere}

According to Article 12 of the Convention on the Rights of the Child, States Parties shall ensure to the child who is capable of forming a judgment of his own the right to express his views freely in all matters affecting the child. Taking due note of a child's views depending on age and maturity is extremely important. In addition, the article states that the child shall be given the opportunity to be heard in any judicial and administrative proceedings affecting the child, either directly, or through a representative or an appropriate body, in a manner consistent with the rules of procedure of the national law of the country concerned.

From its interpretation of the above Convention and in line with Article 4 of its Constitution, the Mexican Judiciary has established the guidelines ${ }^{67}$ to be observed when children participate in any legal proceeding that may affect his legal sphere. These guidelines always take the best interests of the child into account. For instance:

1) For the admission of the proof, the biological age of children is not considered the determining criterion to reach a decision regarding their participation in a legal proceedings, but their maturity. The common practice of interviewing children relentlessly or unnecessarily should be avoided in these procedures and their right to participate should be respected.

2) To prepare for an interview in which children will participate, the child must be informed in accessible and friendly language about the procedure and his right to participate, and it is necessary to ensure that his participation is voluntary.

3) For the submission of the evidence, the child's statement or testimony must be given at a hearing under the structure of an interview or con-

67 See "Derecho de los menores de EDAD a PARTicipar en los Procedimientos JuRisdiccionales Que afecten su esfera jurídica. Lineamientos para su ejercicio”, Primera Sala de la Suprema Corte de Justicia de la Nación [S.G.J.N.] [First Chamber of the Supreme Court of Justice] Semanario Judicial de la Federación y su Gaceta, Decima Época, libro XVIII, Marzo 2013, Tesis 1st. LXXIX/2013, Página 884 (Mex). 
versation, which must comply with certain requirements. It is advisable that, prior to the interview, the judge will meet with a specialist in child welfare, either a psychiatrist or a psychologist, to clarify the terms of what they intend to discuss with the child, so as to make it easier to understand and continue the conversation. The interview should take place, whenever possible, in a place that does not represent a hostile environment for the best interests of the child. This should be somewhere he can feel safe and respected when freely expressing his views. In addition to the presence of the judge or the judicial authority, the specialist in child affairs who has previously met with the judge must also appear during the diligence and whenever the child so requests or it is deemed appropriate to protect the child's best interests, a trusted person may also be present, provided it does not generate a conflict of interest. To the greatest possible extent, the child's statement or testimony should be recorded in full, either through a transcript of the entire proceeding or technological means in a court environment that enables audio recording.

4) Children must participate directly in the interviews, but this does not imply that they do not have legal representation during the trial, the responsibility of which will fall on those who are legally called to exercise it, except in the case the need to appoint a child advocate is deemed necessary.

5) The child should be consulted about the confidentiality of his statements, although the final decision lies with the judge, to avoid any conflict that may affect his mental health or general well-being.

Finally, the right of minors to participate in judicial procedures contributes to the comprehensive protection that is directly linked with the principle of equality as an essential element of formality in the procedure.

\section{Cases of Cohabitation of Parents with the Child for Reasons of Divorce, Guardianship and Custody, Parental Rights and Adoption}

The provisional measures that can be adopted in a divorce trial have legal bases. ${ }^{68}$ This consists of having the opposing party present at the hearing to determine the provisional guardianship and custody of the minors of the marriage and the corresponding visitation arrangements. In the case of any disagreement, the minors should be heard so that their best interests are respected. It should be noted that as it is a provisional measure, the Court does not have all the evidence needed to issue judgment in strict adherence to the

68 This can be viewed in Articles 282, 941 Bis and 941 Ter from 282, 941 Bis and 941 Ter; Código de Procedimientos Civiles para el Distrito Federal [C.P.C.D.F.] [Civil Procedure Code of the Federal District], as amended, Diario Oficial de la Federación [D.O.], 26 de mayo de 1928 (Mex.). 
real situation and must therefore observe the legal and human presumptions, as long these are not distorted, which will depend on the subsequent actions to be verified during the trial. The absence of evidence regarding the parent's actual behavior does not constitute an impediment to issuing decision to protect the best interests of the child, insofar as it deals with determining who shall exercise the guardianship and custody of children and the visitation and cohabitation arrangements, which will influence the child's physical and emotional development. In order to do so, judge requires minimum weighting to enact his decision. ${ }^{69}$

\section{The Principle of Guardianship, Custody and Parental Authority of the Parents Consisting in the Fact that Minors Should Not Be Separated from Their Parents against the Will of the Parents in Weighting the Best Interests of the Child}

If there is any indication that following the transfer of a minor to the care of one of his parents as ordered by the sentence, the child's psychological and physical integrity is affected due to harmful behavior after the ruling is enforced, resulting in clear signs of violence, and if the family court judge knows of any indication that puts the best interests of the child at risk, compliance with the final ruling must be reconsidered under said principle. Prior to ordering the execution of a sentence, the judge must have at his disposal all the evidence needed to assess whether the sentence should be enforced or not.

Another constitutional principle in place is that of legal security, meaning that final sentences of ordre public and general interest must be enforced, but this does not apply in the case of family disputes. This principle cannot be set above the best interests of the child. In this case, the fulfillment of such a sentence would lead to exposing the child to all kinds of dangers ranging from physical and psychological aggression to sexual molestation that can mark a child for life. ${ }^{70}$

\section{Legal Adoption by a Same-Sex Partnership and the Principle of the Best Interests of the Child}

Just like any human being, children enjoy fundamental rights recognized in various international instruments which have established that due to their

69 See Medidas provisionales en un Juicio de divorcio que afectan a menores. Datos que deben tomarse en cuenta para decretarlas. Tribunal Colegiado de Circuito [T.C.C.] [Collegiate Circuit Court], Semanario Judicial de la Federación y su Gaceta, Novena Época, tomo XXXIII, Abril 2011, Tesis I.3o.C.923 C, Página 1340 (Mex).

70 See INTERÉS SUPERIOR DEL MENOR. DEBE PONDERARSE SU PREFERENCIA EN RELACIÓN CON otros principios constitucionales atento al caso concreto, Tribunal Colegiado de Circuito [T.C.C.] [Collegiate Circuit Court], Semanario Judicial de la Federación y su Gaceta, Décima Época, libroVI, Marzo 2012, Tesis I.3o.G.1022 C, Página 1222 (Mex). 
lack of physical and mental maturity, children need protection and special physical, mental and legal care, both before and after birth. This protection is guaranteed when the State seeks to provide the necessary means so that the child's family can give this care and protection. It is thus deemed that the ideal setting for a child's optimum development is found in the bosom of a family in an environment filled with happiness, love, respect and understanding, with the participation of both parents, insofar as this does not go against the best interests of the child.

Consequently, it is the obligation of both the Mexican State and the parents to ensure the normal development of a minor -the one that is produced when the child's environment allows or makes this development possible according to the child's physical and mental capabilities to prepare for an independent life in society with a perception of respect since others also have rights. But the legal possibility of adoptions for same-sex unions does not constitute automatic or indiscriminate authorization to do so, nor does this happen with heterosexual couples. Adoptions must adhere to the legally established system, as it aims to ensure the best interests of the child as a fundamental right of the adoptee. ${ }^{71}$

\section{The Best Interests of the Child and the Tender Years Doctrine}

The Mexican Supreme Court of Justice has interpreted Article 4 of the Constitution to mean that the best interests of the child should be the guiding rule that applies equally to the father and the mother in terms of satisfying a child's needs and consequently the attainment of his comprehensive development. Meanwhile, the State also has the constitutional ability to separate the child from one or both of his parents in order to provide the child greater protection. The Constitution does not establish a general rule stating that a child's comprehensive development can only be guaranteed when he is with his mother. The judge is entitled to assess the specific circumstances of each case to guarantee the child respect for his rights. Consequently, if men and women are equal before the law and in particular with regard to the care and protection of their children, both are responsible for ensuring the best interests of the child are met. It is clear that if a child must be separated from one of his parents, the Article 4 of the Mexican Constitution does not establish a fundamental principle that automatically gives custody to the mother. ${ }^{72}$

71 See Matrimonio ENTRE PERSONAS DEL Mismo SEXo. La POSIBILIDAD JURídica DE QUE PUEDAN ADOPTAR NO DEBE CONSIDERARSE COMO UNA AUTORIZACIÓN AUTOMÁTICA E INDISCRIMINADA. (ART 391 del Código Civil para el Distrito Federal), Tribunal Colegiado de Circuito [T.C.G.] [Collegiate Circuit Court], Semanario Judicial de la Federación y su Gaceta, Novena Época, tomo XXXIV, Agosto2011; Tesis P./J. 14/2011, Página 876 (Mex).

72 See Interés superior del Menor. En Caso de Que Deba SER SEPARAdo DE ALGUNO DE SUS PADRES, Primera Sala de la Suprema Corte de Justicia de la nación [S.G.J.N.] [First Chamber 


\section{Conclusion}

The Mexican legal system establishes different rights of a personal and social nature in favor of children. This can be observed at the level of the Constitution and international treaties, as well as in federal and local laws.

In the various regulations, the legal protection of minors allowed the best interest of the child to be recognized as a principle. This implies that the policies, actions and decisions related to this stage of human life are carried out in such a way that the direct benefit of the child at whom it is directed takes first place. With this aim in mind, work is being carried out from a legal and jurisprudential perspective to shape the content of this constitutional principle, which also pertains to family law.

The best interests of the child have entered the ranks of what the Supreme Court of Justice of the Mexican nation calls the "hard core of rights". These are identified as those that do not admit any restriction whatsoever, and therefore also touch upon legislators when the legal regulations expressly recognize the cluster of rights and order that the mandate be made effective. With an updated legal assumption to achieve the function of this principle, a series of obligations have arisen that State authorities need to meet, including a case-by-case analysis. This aspect implies the recognition of a "hard core of rights", which are rights that do not allow any restrictions and therefore, constitute an insurmountable limit that particularly has a bearing on legislature. In addition to protecting the best interests of the minor, it also protects the right to life, the right to nationality, the right to identity, the freedom of thought, the freedom of conscience, the right to health, the right to education, the right to an adequate standard of living and the right to engage in age-appropriate activities.

The best interests of the child as a guaranteed principle also denotes an obligation to prioritize public policies aimed at ensuring the "hard core" of rights, but that is not all. It is imperative to turn to the argumentative method of weighting, which consists of analyzing each individual case when conflicting situations arise that involve the interests of third parties. This must be carried out in such a way that the scope of the best interests of the child is set according to the particular circumstances of the case and may not entail the exclusion of the rights of others.

of the Supreme Court of Justice] Semanario Judicial de la Federación y su Gaceta, Novena Época, tomo XXXIII, Febrero 2011; Tesis 1st. VII/2011, Página 615 (Mex).

Recibido: 6 de mayo de 2014. 